ISSN 1676-3742

\title{
A Esperança como Teologia da História (II) na V Conferência Episcopal de Aparecida
}

Lina Boff

\section{Resumo}

Busca-se fazer uma leitura do Documento de Aparecida, extraindo dele a esperança vivida pelos nossos povos como experiência de fé que constrói uma história de partilha, de solidariedade e de comunhão e participação. O objetivo principal é resgatar o espírito e o entusiasmo missionário e profético das Conferências anteriores, de modo especial a de Medellín (1968) e a de Puebla (1979), com as quais as nossas comunidades de fé exultavam de alegria e coragem, ao aplicar as orientações dadas pelos bispos daquele tempo. Os anos de 60 a 80/85 foram anos de exultação e produção teológica em quase todos os segmentos da Igreja e da Sociedade. Foi também um tempo em que fizemos boa aproximação com grande parte das pessoas de boa vontade de outros segmentos sociais da sociedade e até mesmo da Igreja; os evangélicos nos admiravam e começamos a fazer projetos juntos e trabalhar para o Reino de Deus com todas as forças da nossa esperança e da nossa fé em Cristo, Senhor da história e ressuscitado para toda a humanidade. Não podemos perder este élan e nem nos amedrontar diante do novo que vem desabrochando sempre mais. Se não pudermos avançar para frente, avancemos pelos lados, porque Deus caminha conosco na história. Arregacemos nossas mangas e partamos para o serviço-poder que nos espera nesta caminhada. 
Palavras-chave: Fé e Esperança, História e Conversão, Discipulado e Missão.

\section{Riassunto}

Cercasi di fare uma lettura del Documento di Aparecida traendo 1`speranza vissuta daí nostri popoli come sperienza di fede che costruisce uma storia di condivisione, de solidarieta e di comunione e partecipazione. L'obiettivo principale è riscattare lo spirito e l'entusiasmo missionario e profetico delle Conferenze anteriormente celebrate, in modo speciale, rifaccendosi a Medellín (1968) e a Puebla (1979), eventi dello Spirito che hanno portato i nostri popoli ad uma esultazione di gioia e profezia nell applicazione, nella nostra realta, con orientamenti pastorali dei nostri pastori e vescovi. Verso gli anni 60 a 80/85, essi costituirono um tempo di esultazione e produzione teologica in tanti segmenti e strati culturali della Chiesa e della Societa. Fu anche um tempo di grande aprossimazione com i fratelli e sorelle evangelici, con le donne e gli uomini di buona volonta, ma che niente o poco credevano nella forza della fede e della speranza nutrite e vissute dai cristiani. Non possiamo perdere questo élan e neanche ad avere paura o timore davanti al "nuovo" che viene sbocciando sempre piu da varie parti, sia all interno della Chiesa, sia nella Societa globalizzata e globalizzante in cui viviamo. Urge rimboccchiarci di fede nella speranza di costruire uma nuova storia che comincie la realizzazione della "promissio" fatta dal Signore, centro e fine di tutta la storia.

Parole-chiave: Fede e Speranza, Storia e Conversione, Discepolato e Missione.

\section{Introduzindo o assunto}

$\mathrm{Na}$ primeira parte deste artigo procuramos expor a esperança como teologia da história relendo as Conferências Episcopais de Medellín (1978)1, Puebla $(1979)^{2}$ e Santo Domingo (1992) ${ }^{3}$, artigo que se encontra às páginas 133

\footnotetext{
${ }^{1}$ CELAM, A igreja na atual transformação da América Latina à luz do Concílio. Conclusões de Medellín, Conselho Episcopal latino-americano, Petrópolis, Vozes, 1970.

${ }^{2}$ CELAM, A evangelização no presente e no futuro da América Latina. Puebla: Conclusões, S. Paulo, Loyola, 1979

${ }^{3}$ CELAM, Nova evangelização, promoção humana, cultura cristã, Santo Domingo, IV Conferência Geral do CELAM, Petrópolis, Vozes, 1992.
} 
a 153 (2010), desta Revista ${ }^{4}$. Agora, pensamos em dar um espaço à Conferência de Aparecida que se nos apresenta de maneira ainda bastante próxima da nossa ação pastoral e da reflexão que caracteriza o nosso modo de fazer teologia, a partir da realidade concreta, em que vivemos a nossa fé.

Esta segunda parte do artigo se propôs refletir a esperança como teologia da história, partindo da experiência latino-americana e caribenha vivida pelos nossos bispos em Aparecida, junto com o povo que fazia uma espécie de guirlanda pelo lado de fora, em torno a Nossa Senhora, e, portanto, próximos a um povo romeiro que vai ao Santuário para renovar sua fé e suas forças, diante dos desafios que o cotidiano lhe apresenta. Os bispos querem fazer desta Conferência um momento novo de todos os povos do extenso Continente, eles querem trabalhar no espírito de um novo Pentecostes. A nosso ver, este propósito, experimentado num clima de Santuário Mariano Popular, levou os bispos a elaborar um Documento final que resume as conclusões de seu diálogo com as próprias Conferências Episcopais entre si, com o povo e com a igreja institucional.

A Conferência de Aparecida, portanto, dá uma atenção especial às situações que manifestam significativo declive da Igreja como anunciadora da Boa Nova a uma sociedade aberta à globalização e suas conseqüências para as culturas e as tradições de fé de cada povo do extenso Continente. Se a Igreja e as estruturas eclesiásticas têm como primeira finalidade anunciar Jesus Cristo e criar comunhão e participação de todos, deve-se, portanto, levar em conta a necessidade de concentrar os esforços de todas as expressões culturais e de fé, em tudo aquilo que une, para que nossos povos tenham vida, e vida em Cristo.

Se nas três primeiras Conferências Episcopais, realizadas em nosso Continente, a intuição do Vaticano II deu um sentido cristão à esperança e às angústias dos povos do mundo inteiro, agora, mais do que nunca, os bispos buscam a construção de uma história transformadora, "mudando de casa", pois, trata-se de "uma mudança de época" que urge um jeito novo de ser discípulas e discípulos missionários da Boa Nova, numa cultura em que a transmissão da fé de geração para geração, a dignidade humana e a desigualdade social persistem numa sociedade globalizada, que expulsa as relações de solidariedade e de cooperação.

A esperança vivida neste contexto histórico de fé cristã é concebida como teologia da história, pois, esta tem a missão de ver a realidade e julgar os fatos e os acontecimentos que transcendem a história humana, à luz do Evangelho,

${ }^{4}$ Atualidade Teológica (ATeo), Ano XIV, fasc. 35 (maio/agosto, 2010), p. 133-153. 
para continuar construindo a História da salvação ${ }^{5}$. Reconhecemos que muitas foram as publicações que procuraram interpretar e analisar a Conferência sob seus diferentes aspectos.

O nosso objetivo, neste artigo, é falar de uma concepção de esperança que dê, à história, um sentido de fé, teológico, portanto, como fizemos na primeira parte. Como o Documento da V CELAM quer ser um novo Pentecostes, estruturamos o mesmo em três partes. A primeira considera, brevemente, o sujeito que olha a realidade. A segunda parte considera que este sujeito olha, antes de tudo, para Jesus Cristo como fonte de vida, para enxergar melhor a realidade que o envolve. E a terceira parte leva o sujeito a entrar, plenamente, na missão atual da Igreja continental, sem perder o discernimento da realidade, nem os fundamentos teológicos da própria fét. Em todo o Documento pode-se sentir o desejo e a preocupação que os bispos vivem: constatam que há um significativo retrocesso da Igreja em muitas frentes que foram abertas e levadas adiante com coragem profética, sobretudo, a partir de Medellín. E agora, nesta Conferência, a medida dos passos dados e omitidos, torna-se um desafio histórico para os bispos despertar a esperança que precisa ser vivida e testemunhada no zigue-zague de pecado e graça.

O Documento conclui num tom evangélico e pastoral com uma linguagem direta e propositiva, convocando batizados e batizadas a proclamarem, com audácia, Jesus Cristo a serviço da vida em plenitude.

\section{A esperança como teologia da história na intuição do Documento de Aparecida}

Uma primeira leitura que se faz deste Documento nos induz a dizer que a esperança como teologia da história se encontra dentro de um tratado de teologia espiritual, o qual orienta a vida de fé dos pastores e dos nossos povos a se tornarem discípulos e discípulas missionários para terem uma prática cristã transformadora da realidade. Esse tratado de teologia espiritual fala da esperança, já na sua introdução, como uma das maiores riquezas dos nossos povos, mas que é ameaçada pelo medíocre pragmatismo da vida cotidiana de cada pessoa, de toda a sociedade e da Igreja.

\footnotetext{
${ }^{5}$ Cf. BALTHASAR, H. U. von, Verbum caro. Saggi Teologici 1, Brescia, Morceliana/Milano, Jaca Book, 2005, p. 45

${ }^{6}$ Cf. IMPERATORI, M., H.U. von Blathasar: Uma teologia darmmatica della storia. Per uma discernimento dialógico nella modernita, Pontifício Seminário Lombardo in Roma, 2001, 537ss.
} 
Contudo, a esperança como teologia da história, neste Documento, não foi tão incisiva e nem foi lembrada com tanta força como em Medellín e Puebla. Mas decidimos falar dessa esperança começando pelos pronunciamentos do papa, pois, o Documento elaborado pelos bispos do nosso Continente pouco fala de esperança, enquanto o papa, em seus discursos e homilias, falou muito mais dessa esperança, do que mesmo o Documento que traçou as orientações pastorais para os próximos dez anos, no Continente.

A carta de Bento XVI que legitima e aceita a publicação do Documento de Aparecida, datada em 29 de junho de 2007, convoca a todos e a todas recomeçarem a história partindo de Cristo, para buscar águas mais profundas ${ }^{7}$, para que se possa manter viva a esperança, e continuar esperando contra toda a esperança que não engana, porque a nossa esperança está em Jesus $\mathrm{Cristo}^{8}$. Na homilia da celebração eucarística que abre a Conferência de Aparecida, por exemplo, Bento XVI fala de três elementos importantes que merecem ser sublinhados, neste artigo, porque se referem à esperança como teologia da história.

Em primeiro lugar ele afirma que a fé vivida, na história, pelos nossos povos, faz da América Latina o Continente da Esperança. No entanto, esta fé se concretiza no Deus Amor que se encarnou, morreu e ressuscitou em Jesus Cristo, autêntico fundamento da esperança. Prossegue afirmando, ainda, que esta esperança produziu frutos tão magníficos que perpassa os quinhentos anos de evangelização e continua, ainda hoje, a produzir frutos.

A esperança que faz história se entrelaça com a história de hoje, quando o pontífice fala do testemunho de Santos e Beatos que a força do Espírito suscitou ao longo e ao largo do nosso Continente'. Tal testemunho é imagem da esplêndida beleza da Jerusalém celeste apresentada pelo Apocalipse do João (cf. Ap 21,10). Este testemunho vivo que a Igreja dá ao mundo inteiro, através de seus Santos e Santas, seus Beatos e Beatas do Continente, atualiza a figura nupcial que encontramos em toda a revelação bíblica e apontam para a universalidade da fé cristã. Esta não necessita de templo algum, nem de fonte externa de luz, porque a presença do Deus Amor é imanente e a ilumina desde dentro ${ }^{10}$.

${ }^{7}$ CELAM, Documento de Aparecida. Texto conclusivo da V Conferência Geral do Episcopado Latino-Americano e Caribenho (DAp), S. Paulo/Brasília, Edições CNBB, Paulus, Paulinas, 7.1217; Cf. Novo Millenio ineunte, 28-29.

${ }^{8} \mathrm{DAp}, 12$.

${ }^{9}$ Cf. BENTO XVI, "Santa missa de inauguração da V Conferência Episcopal da América Latina e do Caribe, na Praça em frente ao Santuário de Aparecida - Homilia (13 de maio de 2007)", in Documento de Aparecida (DAp), p. 253

${ }^{10}$ Ibid., p. 254. 
O pontífice manifesta, aqui, a força da esperança que os povos do Continente vivem na fé do Cristo que faz historia junto com seu povo e o motiva a iluminar o mundo com o Deus Ágape, o qual realiza a esperança que faz história e aponta para a vida plena testemunhada pelos nossos mártires. Esta opção que leva ao martírio não fica clara nas palavras do pontífice, pois, a análise da nossa realidade, em documentos eclesiais latino-americanos anteriores, vem muito ligada ao lugar da "opção preferencial pelos pobres" e à metodologia do ver-julgar-agir. Mais adiante, os bispos interpretam que esta opção preferencial deva atravessar todas as nossas estruturas e prioridades pastorais ${ }^{11}$. Neste contexto, os bispos recuperam o sentido originário dado nas Conferências anteriores deste grande avanço da nossa Igreja, o qual se expressa na prática da fé dos povos do extenso Continente.

Em segundo lugar, irrompe o elemento universal da fé, na sua originalidade, pois, a celebração da Conferência, não é só um momento de graça para o Continente, mas para o mundo inteiro. A homilia emprega duas categorias para falar de um fato histórico que marca a vida dos nossos povos. A primeira considera dom especial da Providência a celebração de mais uma Conferência Episcopal, neste tempo e neste lugar ${ }^{12}$.

Com a palavra "tempo", liga-se o momento histórico do presente ao nascimento da Igreja em Pentecostes, tempo litúrgico em que a Igreja intensifica sua preparação para receber o Espírito Santo que se atualiza na comunidade de fé. Refere-se ainda, ao Espírito que desce sobre toda a carne (cf. At 2,17). Trata-se, portanto, da encarnação do mesmo Espírito que levou Jesus a realizar o Projeto do Pai. É na celebração litúrgica que a Igreja encontra a raiz da esperança, que testemunha o futuro da humanidade.

A segunda categoria usada refere-se ao "lugar" em que a Conferência se dá, lugar que fala da fé mariana dos nossos povos, fé coroada com a celebração do Grande Sinal - o Sacramentum caritatis - momento de graça, não só para o Continente, mas para o mundo inteiro. Encontra-se aqui, a categoria teológica que abre a fé popular para a universalidade, no hoje da nossa história, para que Cristo possa continuar a "fazer-se carne"

Esta última expressão, "fazer-se carne", é o forte componente feminino da espiritualidade cristã dos nossos povos, que crêem não só porque compreendem e apreendem as coisas da fé e do Deus que lhes fala, na história, mas

\footnotetext{
${ }^{11}$ Cf. DAp., 396.

${ }^{12}$ Cf. DAp., pág. 249s.

${ }^{13}$ Cf. BENTO XVI, “Homilia de 13 de maio de 2007”, o.c., p. 250-253.
} 
porque vivem e praticam aquilo que crêem para melhor compreenderem. Tal processo de fé, do nosso povo peregrino, não é evadir-se da realidade histórica, mas compartilhar as alegrias e as esperanças dos mais pobres e dos que sofrem $^{14}$. No Documento, esta realidade é expressa com certo pessimismo e o tópico dos "sinais dos tempos", não aponta para o seu conteúdo.

No discurso inaugural dos trabalhos, o pontífice fala de esperança por três vezes, somente. Apresenta em breve, as mudanças havidas depois da Conferência de Santo Domingo, e retoma o primeiro parágrafo da Gaudium et spes - que fala das alegrias e as esperanças dos pobres e dos que sofrem. Estas são também as alegrias e as esperanças dos discípulos e discípulas de Cristo. Afirma também que a Igreja está sempre pronta a caminhar ao lado dos nossos pastores e dos nossos povos, para infundir-lhes a esperança que se funda em Cristo. Pois, diante das mudanças e dos desafios de ordem cultural, política, econômica e religiosa que o Continente enfrenta, os fiéis esperam, desta Conferência, renovação e revitalização da fé cristã, que se expresse em novos caminhos e projetos pastorais criativos, que infundam a firme esperança de viver a fé de maneira responsável e gozosa, com o objetivo de irradiá-la em seu ambiente ${ }^{15}$. Ao pedir que o Senhor fique conosco, despede-se com a firme esperança que nutre no Senhor.

Pode-se dizer que a intuição que o Documento de Aparecida apresenta sobre a esperança como teologia que se funda em Cristo e irrompe do contexto histórico do nosso Continente, vem dos pronunciamentos do papa que abre a Conferência. A seguir, as discussões e os debates feitos pelos bispos assessorados por teólogos e teólogas, cientistas sociais e pastoralistas, tem, como eixo principal, o testemunho de vida, o chamado do Senhor que nos pede olhar a realidade como discípulos e discípulas missionários que anunciam a Boa Nova; que julgam esta realidade a partir da vocação à santidade; e finalmente, atuam na missão da Igreja e do Mundo como discípulos e como missionários dentro do itinerário marcado por uma espiritualidade trinitária, cristocêntrica e mariana. Pois, o homem das esperanças de todos os séculos já emergiu na história, atingiu a meta como total transfiguração da existência humana, saindo das estreitezas do nosso jeito de fazer história com esperança ${ }^{16}$.

${ }^{14}$ Cf. BENTO XVI, "Homilia de 13 de maio de 2007”, p. 254-255.

${ }^{15}$ Cf. BENTO XVI, "Sessão inaugural dos trabalhos da V Conferência Geral do Episcopado da América Latina e do Caribe, na sala de Conferência do Santuário de Aparecida - Discurso (13 de maio de 2007)", in Documento de Aparecida. Texto conclusivo da V Conferência Geral do Episcopado Latino-Americano e do Caribe, S. Paulo/Brasília, CNBB/Paulus/Palulinas, 2007, p. 270-271.

${ }^{16}$ Cf. BOFF, L., A ressurreição de Cristo. A nossa ressurreição na morte, Petrópolis, Vozes, 1972, 
A nossa tentativa, agora, é falar da esperança como teologia da história em cada parte do Documento, partindo de cada uma das três partes em que o mesmo recorre à esperança como elemento teológico que transforma a História da salvação, na caminhada de fé dos nossos povos.

\section{A esperança na vida dos nossos povos, hoje: Primeira Parte}

Podemos afirmar que o conceito central desta primeira parte do Documento, segundo a leitura feita por teólogos e teólogas que acompanharam a Conferência, se concentra em dizer que todos nós, homens e mulheres, precisamos recomeçar a partir de Cristo a fim de olhar a realidade em seu conjunto e discerni-la à luz do Evangelho. A partir deste conceito central, o primeiro sinal de esperança que brota do caminhar histórico dos nossos povos, vem da presença cotidiana e cheia de confiante expectação dos romeiros e romeiras que acorrem ao Santuário de Aparecida do Norte.

Nesta primeira parte, que fala do discipulado missionário, a esperança é sentida e é percebida, no contexto em que se dá a Conferência. Por isso, os bispos falam que esta esperança é vivida, também, na presença cotidiana do número incontável de peregrinos e peregrinas que acorrem ao santuário, com a mesma esperança com que os discípulos de João Batista acorriam ao batismo da penitência, na esperança de encontrar o Messias ${ }^{17}$.

A interpretação que os bispos fazem dos fatos da vida cotidiana dos fiéis, estabelece a dinâmica da fé que liga a experiência cotidiana à mensagem bíblica do Precursor de Jesus, o Batista. Esta dinâmica se concentra na esperança do advento que aponta e sinaliza para as realidades que ainda não se vêem, mas que o povo acredita em tais realidades, porque nelas se realiza a Promessa. Pois, a fé é a substância das coisas que os peregrinos e as peregrinas esperam.

No quadro desta interpretação, dada pelos pastores aí reunidos, eles afirmam que a esperança é sentida e percebida, como dom do Senhor que se manifesta nos dons dos nossos povos em processo de evangelização. Esta evangelização vem conectada à promoção humana e à autêntica libertação cristã $^{18}$. Percebe-se evocações de conceitos dados à esperança cristã, da Carta

p. 15-16. Faça um cf. também com POLITI, S., História e Esperança, S. Paulo, Paulinas, 1996, sobretudo às p. 206s em que o autor destaca que a construção da história do tempo presente já é uma resposta que antecipa o Reino da plenitude.

${ }^{17}$ DAp., 21.

${ }^{18}$ DAp., 22; 26. 
Encíclica Spe salvi publicada em $2007^{19}$. Por isso tudo, em tom de hino e canto de ação de graças, os bispos louvam a Deus Pai que derramou tantos dons sobre nossos povos.

A Conferência volta-se para o reconhecimento destes dons. O dom da palavra concedido ao discipulado que ouve o chamado do Senhor, realiza a missão da Igreja, que é evangelizar, anunciar que o Pai enviou seu Filho Jesus Cristo a todos e a todas. Ele está perto com seu poder salvador e libertador; que nos acompanha na tribulação, alenta, incessantemente, a nossa esperança em meio a todas as provações. Esta consciência leva mulheres e homens a serem portadores e portadoras da Boa Nova, profetas e profetisas de esperança ${ }^{20}$. Com este olhar de discípulos e discípulas que testemunham a esperança que não delude, lançam seu olhar sobre a realidade que os envolve.

Ao longo do Documento, vamos encontrar uma posição um tanto mais voltada para a nossa realidade conturbada, quando os bispos se pronunciam a favor de que se deve fazer uma teologia contextual, articulando os dois níveis da fé: a análise da realidade a partir da opção pelos pobres, que significa "ver Deus no rosto dos pobres", sem permitir o abandono da realidade sociológica, nem sua redução aos problemas econômicos, sociais e políticos. Mas, igualmente, não se permite voltar a uma fé desencarnada e a um Pai-Nosso sem pensar no "pão de cada dia", que a humanidade está pedindo e suplicando ao Único Pai.

A concepção de esperança, na fé, encontrada nesta primeira parte, é esperança que consente a alegria, o gozo, a solicitude e o compromisso com a promoção humana e a partilha dos bens do tempo presente, que estão a serviço da vida. Esta concepção leva a teologia a uma reflexão ontológica sobre a temporalidade da vida humana, sua história e sobre toda a criação ${ }^{21}$. É a esperança que direciona a chamada "mudança de época", é a esperança que desinstala as estruturas e mostra os distintos caminhos da prática da fé. Enfim, a esperança tem a missão de nos encaminhar à plenitude da Promessa realizada em Jesus Cristo.

\footnotetext{
${ }^{19}$ Cf. BENTO XVI, Carta Encíclica Spe Salvi, sobre a Esperança Cristã, S. Paulo, Paulus/Loyola, parágrafo 7. Um comentário sobre esta Carta Encíclica foi publicado na REB/68, fasc. 271, julho de 2008, pela autora, com o título, "a Spe salvi sugere o Vaticano II? Do Continente da Esperança", pp. 653-670.

${ }^{20}$ DAp., 30

${ }^{21}$ Há um potencial, fortemente, hermenêutico nesta concepção do autor que agora citamos: KEHL, M., "E Dio vide che tutto era cosa buona". Una teologia della creazione, Brescia, Queriniana, 2009, p. 349.
} 


\section{Ressonâncias teológicas vindas do contexto histórico}

Os bispos não se calam ao afirmar que a realidade do tempo presente precisa ser transformada, pois, não responde às aspirações e esperanças dos povos que habitam o Continente da Esperança. Basta ver, o parágrafo 65 que apresenta os rostos daqueles e daquelas que sofrem. Os bispos levam em conta os rostos empobrecidos que encontramos nas Conferências anteriores e acrescenta, com ênfase, a presença desafiante dos rostos da sociedade moderna.

Em primeiro lugar estão as comunidades indígenas e afro-americanas. A seguir temos a exclusão das muitas mulheres, excluídas por serem mulheres, fenômeno de exclusão social que joga fora as pessoas como coisas supérfluas e descartáveis; e aqui encontramos os meninos e meninas de rua, as pessoas com limitações físicas, jovens drogados em busca de sentido e sem ponto de referência, cidades privadas de segurança, anciãos incômodos e rejeitados e por aí vai a leitura dos bispos 22 .

A esperança proposta pelo Documento de Aparecida, é uma esperança na pessoa do Cristo Senhor da glória, vivido e anunciado na prática do amor aos rostos sofredores do nosso Continente ${ }^{23}$. A concepção de esperança que aqui se apresenta, tem a ver com a realidade concreta que se encontra num contexto histórico. Este contexto exige e urge uma nova construção da história humana e uma nova atuação do ser humano para esta construção. Pode-se constatar a profunda interseção existente entre o estatuto do discípulo missionário e sua missão no Continente, que faz da esperança uma ação concreta de fé que muda a história, porque se concretiza no encontro da pessoa com Cristo que a envia em missão.

A esperança autêntica não olha para a Promessa de maneira passiva, mas convoca a construir uma nova história que mude as condições de vida, as quais impedem a realização do Projeto do Pai, aqui e agora, para a justiça e a paz $^{24}$. É um olhar da fé que leva à prática que dela resulta. O Documento analisa com acuidade os vários processos históricos em seus distintos níveis: sócio-cultural, econômico, sócio-político, étnico e ecológico. Descobre os grandes desafios para a evangelização e a injustiça estrutural que povoa o fenômeno da globalização tão complexa.

\footnotetext{
${ }^{22}$ Documento de Aparecida, 65.

${ }^{23}$ DAp., 44: "Vivemos uma mudança de época, e o seu nível mais profundo é o cultural".

${ }^{24}$ Cf. Gaudium et Spes, 21. 34. 39.
} 
As mudanças do nosso Continente sofrem a influência das mudanças que atingem todos os Continentes. São mudanças sociais, políticas, culturais, religiosas, históricas, que afetam os critérios de apreender, compreender e julgar a realidade as quais foram cunhadas como mudança de época ${ }^{25}$. As mudanças e as sombras que se vêem têm um alcance global, à diferença do que ocorre em outras épocas, sobretudo, nas Conferências anteriores. Frente a este fator globalizante, os bispos sentem forte o chamado a fazer uma proposta de promover uma globalização marcada pela solidariedade, pela justiça e pelo respeito aos direitos humanos, indo além de sermos o Continente da Esperança, para sermos o Continente do Amor ${ }^{26}$. Este amor se concretiza na aproximação do discipulado aos novos rostos sofredores da nossa América Latina e do Caribe.

Deve-se reconhecer que os bispos mostraram profunda sensibilidade ao descrever tais rostos. Colocam, em primeiro lugar - repetimos o parágrafo pela sua beleza teológica e viva - o rosto das comunidades indígenas e afro-americanas, as mulheres excluídas por serem mulheres e os jovens impedidos de se desenvolverem na sua vocação integral. A nosso ver, poderíamos colocar estes rostos como que "condenados" a viver esta pobreza, porque imposta pela condição de serem pessoas humanas sem opção de vida em toda a sua expressão de vida querida pelo Criador. Estes rostos humanos são o resultado de uma sociedade globalizada que ignora o valor da solidariedade, não se interessa pela justiça e nem pelos direitos humanos. Frente a tal sociedade os bispos propõem a vivência e a prática de uma globalização diferente, marcada, portanto, pelos valores que faz do nosso continente o Continente da Esperança e da Solidariedade ${ }^{27}$.

A Conferência orienta o olhar do discípulo, mulheres e homens, a debruçar-se sobre a situação sócio-política de cada país do Continente; reconhece, avalia e alerta, para que as organizações que buscam uma democracia participada, não frustrem as esperanças que nossos povos colocam em tais organizações. Ajudados pelos cientistas sociais, teólogos e teólogas, grupos de várias outras organizações pastorais e voluntárias, que assessoraram os bispos dentro e fora da Conferência, a elaboração do Documento, sintetizaram bem aquilo que os bispos queriam dizer sobre democracia e cidadania, pois estas, andam juntas.

\footnotetext{
${ }^{25}$ Cf. AMADO, J. P., "Mudança de época e conversão pastoral: uma leitura das conclusões de Aparecida", in ATeo, Ano XII, fasc. 30 (setembro/dezembro (2008), p. 303.

${ }^{26}$ DAp., 64.

${ }^{27}$ Cf. DAp., 64
} 
Ao longo dos muitos parágrafos aprovados, o Documento reconhece que a maioria das sociedades latino-americanas e caribenhas, lutam por projetos alternativos de democracia e desenvolvimento. Os movimentos sociais participam, profundamente, desta luta desde o começo da resistência ao regime autoritário, que marcou e vem marcando cada país. Embora o papel positivo dos movimentos sociais na transição para a democracia tenha sido, amplamente, reconhecido pelos analistas sociais e pela Igreja, sua contribuição real e potencial para a expansão e aprofundamento da democracia e do desenvolvimento sócioeconômico, foi questionada. E é o que fazem os bispos, neste ponto.

Esse questionamento sempre privilegiou a dimensão institucional do processo democrático que concebe os movimentos sociais como irrelevantes e até mesmo desestabilizadores para a institucionalização da democracia para o país. Assim sendo, as outras dimensões fundamentais do processo, valorizadas pelos rostos, historicamente, excluídos da democracia representativa tradicional, são, freqüentemente, ignoradas.

Ao destacar a fé, a alegria e a solidariedade de nossos povos, os bispos reconhecem que são qualidades que foram transmitidas, ao longo da nossa história, pelas avós e avôs, pelas mães e pais, pelas catequistas e rezadores e por incontável número de pessoas anônimas que viveram a alegria da esperança em meio às injustiças e adversidades ${ }^{28}$. O parágrafo é concluído com a figura da Mãe de Deus, primeira discípula e missionária ${ }^{29}$.

Cabe destacar, o estímulo dado à Igreja que assume a causa dos pobres, com ênfase ao fato de que os bispos pedem que se dê espaço à participação das pessoas de origem indígena e afro, na vida eclesial, acelerando e qualificando

\footnotetext{
${ }^{28}$ DAp., 26.

${ }^{29}$ A festa da Mãe de Deus é celebrada no dia primeiro de janeiro e foi instituída por Paulo VI, no ano1985, depois do Concílio Vaticano II, que se deu em 1962-65. Entre suas decisões, está a de universalizar a festa de Maria, Mãe de Deus, no dia 01 de janeiro, recuperando um antigo costume. O papa Paulo VI, em sua carta apostólica Marialis Cultus (Sobre o culto a Maria), explicou o significado desta festa: "destina-se a celebrar a parte tida por Maria neste mistério de salvação e a exaltar a dignidade singular que daí advém para a 'santa Mãe..., pela qual recebemos... o Autor da vida'; é, além disso, ocasião propícia para renovar a adoração ao recém-nascido 'Príncipe da Paz', para ouvir ainda uma vez o grato anúncio angélico (cf. Lc 2,14), para implorar de Deus, tendo como a Mãe de Deus 'Rainha da Paz', o dom supremo da paz. Por isso, na feliz coincidência da Oitava do Natal do Senhor, com a data auspiciosa de $1^{\circ}$ de janeiro, instituímos o Dia Mundial da Paz, que vai recebendo crescentes adesões e já matura nos corações de muitas mulheres e homens, frutos de paz". Uma das fundamentações bíblicas para este título dado, encontra-se na exclamação de Isabel ao receber Maria de Nazaré em sua casa: "Donde me vem que a Mãe do meu Senhor me visite"? (Lc 1,43).
} 
o processo de inculturação, como fazer traduções católicas da Bíblia e textos litúrgicos no idioma destes povos, assim como promover as vocações e os ministérios ordenados procedentes de tais culturas. Os bispos vêem com esperança o resgate, de forma positiva, para a história do Continente, o processo de ocultamento sistemático que foi feito aos valores históricos e religiosos dos indígenas e afro-americanos. Tal processo não pode ser interpretado como ameaça à pluralidade e à diversidade da nossa história. Este inter-relacionamento histórico caracteriza cada um dos povos que constituem o extenso Continente Sul do Mundo ${ }^{30}$.

Nesta primeira parte do VER, o Documento termina colocando-se diante do desafio dos Meios de Comunicação Social, ainda que escassos, a serviço do anúncio e das atividades que a Igreja realiza. A Doutrina Social da Igreja e sua influência benéfica sobre leigos e leigas, que labutam no âmbito social, político e cultural, é um sinal de esperança, quando socializada pelos Meios de Comunicação Social ${ }^{31}$.

A concepção de esperança como teologia da história que nos vem do Documento de Aparecida, até aqui estudado, pode ser pensada e aplicada a nossa realidade como um dos elementos fundantes da nossa resposta ao chamado do Senhor, para VER a realidade, como pessoas do discipulado, elementos que marcam a história do passado, constroem a nova história do presente conturbado em vista de um futuro solidário e direcionado para a vida em plenitude preparada pelo nosso Deus Uno e Trino, que é a Felicidade completa ${ }^{32}$.

Destacamos o pronunciamento final do episcopado ao encerrar os trabalhos desta Conferência, o qual evidencia que, "No coração e na vida de nossos povos pulsa um forte sentido de esperança, não obstante as condições de vida que parecem ofuscar toda a esperança. Esta se experimenta e alimenta no presente, graças aos dons e sinais de vida nova que se compartilha; compromete-se na construção de um futuro de maior dignidade e justiça e aspira a "novos céus e a nova terra" que Deus nos promete em sua morada eterna" 33 .

\footnotetext{
${ }^{30}$ Cf. Documento de Aparecida, 94 e 97.

${ }^{31}$ Ao colocar a Igreja numa hora histórica de desafios criados por uma globalização que avança sempre mais, sem limites e princípios éticos, os bispos aprovam o parágrafo 99 com seus sete itens e aqui citamos o ítem $f$.

${ }^{32}$ Cf. LUBAC, h. de Cattolicismo. Aspetti sociali del dogma, Milano, Jaca Book, 1992, p. 89s

33 "Conclusão", in Documento de Aparecida, 548; 549; 554.
} 


\section{A esperança na Segunda Parte do Documento: $A$ vida de Jesus Cristo nos discípulos missionários}

O eixo desta segunda parte sublinha a alegria de ser discípulos chamados para a missão; enfatiza a vocação à santidade; fala da comunhão, na Igreja; e dá orientações para o caminho de formação. Esta parte se estende bastante em relação às outras, e aqui é sublinhada a vivência de uma espiritualidade trinitária, cristocêntrica e mariana, encarnada. A nosso ver, encontra-se, aqui, uma das novidades do Documento, que busca revitalizar a vida dos batizados e batizadas para que permaneçam e caminhem no seguimento de Jesus. Extrairemos os parágrafos que interessam ao nosso assunto.

Antes de tudo, deve-se constatar que emerge, em várias partes do Documento, mas de modo especial nesta segunda parte, a importância dada à religiosidade popular. Os bispos falam da piedade popular como uma grande riqueza do nosso povo simples e tantas vezes iletrado. Tratam-na de maneira legítima, através da qual o povo manifesta sua fé, uma fé que o leva a sentir-se parte da Igreja e a sentir-se inserido no processo de evangelização, um jeito especial e criativo de ser missionário ${ }^{34}$.

A Boa Nova da vida se apresenta como um dos caminhos que tem como finalidade valorizar o espírito alegre de nossos povos que amam a música, a dança, a poesia, a arte, o esporte e cultivam uma firme esperança em meio a problemas e lutas. Tal esperança se faz presente e atuante também nas famílias divididas que rezam para superar a ferida da divisão e abrir novos caminhos de esperança $\mathrm{a}^{35}$. O discipulado de mulheres e homens enviados a anunciar o Evangelho do Reino da vida, formados na escola do Mestre, sabem que sem Cristo não há luz, não há esperança, não há amor, não há futuro ${ }^{36}$.

No contexto deste capítulo $\mathrm{V}-$ A comunhão dos discípulos missionários na Igreja - que leva em conta a comunhão da pessoa chamada ao discipulado em missão, na Igreja, os bispos também renovam sua vocação de discípulos missionários que seguem Jesus, Sumo Sacerdote, servidores do rebanho de Cristo, para o qual são chamados a serem mestres da fé para o anúncio da Boa Nova, que é fonte de esperança para todos. Segundo o Documento, os bispos devem ser testemunhas de esperança e pai dos fiéis, especialmente, das pessoas excluídas e dos pobres ${ }^{37}$.

\footnotetext{
${ }^{34}$ Cf. DAp., 264-265.

${ }^{35}$ DAp., 106; 119.

${ }^{36}$ Cf. O Documento que fala disso em seu parágrafo 146, e cita o Discurso Inaugural do pontífice em seu número 3 .

${ }^{37}$ Cf. DAp., 186-187; 189.
} 
O chamado e a missão que irrompem de tal convocação ao discipulado de Jesus Cristo, não só para os bispos, mas para todos os batizados, homens e mulheres, é o pano de fundo de toda esta segunda parte. E a esperança que o povo simples encontra nas via-sacras e no caminhar em direção aos santuários em procissão, já é uma confissão de fé. Estas expressões da religiosidade popular soam como um verdadeiro canto de esperança e a chegada dos romeiros e romeiras ao santuário da peregrinação, é um momento de amor que se prolonga na vida de cada caminhante que vive sua fé e sua esperança em Jesus Cristo ${ }^{38}$. Nesta concepção popular da fé, Deus também vive a mesma esperança do povo peregrino, porque Ele espera a chegada de todos os povos que o buscam e caminham em direção a Ele.

A ênfase dada pelo Documento é a de que, a pessoa chamada por Cristo, olhe a realidade com os olhos da vivência deste chamado; julgue este olhar sobre a realidade conturbada do presente, à luz do Evangelho, pois, é o Evangelho que vai mostrar a missão a ser realizada como resposta aos desafios que, nem a ciência, nem a política, nem a economia e nem os meios de comunicação, poderão dar à busca que satisfaça o coração humano. Nesse sentido, o discípulo e a discípula, chamados por Cristo, buscam um sentido unitário da vida e o prazer de viver a esperança, na história ${ }^{39}$.

Os bispos manifestam uma sadia preocupação com os Centros educativos católicos. Citam a Evangelii nuntiandi ${ }^{40}$, em seu parágrafo 19, onde se

\footnotetext{
${ }^{38}$ DAp., 259

${ }^{39}$ Cf. DAp., 41. Conceito central de todo o documento parece ser encontrado neste parágrafo: “... os cristãos precisam recomeçar a partir de Cristo, a partir da contemplação de quem nos revelou, em seu mistério, a plenitude do cumprimento da vocação humana e de seu sentido. Necessitamos fazer-nos discípulos dóceis, para aprendermos dEle, em seu seguimento, a dignidade e a plenitude da vida. E necessitamos ao mesmo tempo, que o zelo missionário nos consuma para levar ao coração da cultura de nosso tempo, aquele sentido unitário e completo da vida humana que nem a ciência, nem a política, nem a economia, nem os meios de comunicação poderão proporcionar-lhe. Em Cristo Palavra, Sabedoria de Deus (cf. 1Cor 1,30), a cultura pode encontrar seu centro e sua profundidade, a partir de onde é possível olhar a realidade no conjunto de todos seus fatores, discernindo-os à luz do Evangelho e dando a cada um seu lugar e sua dimensão adequada".

${ }^{40}$ PAULO VI, Exortação Apostólica sobre a evangelização no mundo contemporâneo (EN), S. Paulo, Paulinas, 1978, parágrafo 19: "Extratos da humanidade que se transformam: para a Igreja, não se trata tanto de pregar o Evangelho a espaços geográficos cada vez maiores em dimensões de massa. Mas de chegar a atingir e modificar, pela força do Evangelho, os critérios de julgar os valores que contam, os centros de interesse, as linhas de pensamento, as fontes inspiradoras e os modelos de vida da humanidade, modelos que se apresentam em contraste com a Palavra de Deus e com o desígnio da salvação".
} 
encontram alguns critérios que ajudam a discernir a realidade, com a finalidade de transformá-la com a força do Evangelho, antes mesmo que a Igreja amplie seus espaços geográficos de evangelização. $\mathrm{O}$ que conta para a Igreja, que se compromete com o anúncio da Boa Nova, é modificar os centros de interesse de uma sociedade globalizada sem limites, mudar as linhas de pensamento adotadas que não se adequaram ao tempo e às necessidades do povo cristão, transformar as fontes inspiradoras e os modelos de vida que se apresentam em contraste com a Palavra de Deus e com o desígnio da salvação ${ }^{41}$.

A educação que se fundamenta em Cristo, ilumina esta realidade e infunde esperança ao ser humano que se abre ao Deus de Jesus Cristo. Este anúncio cultiva a mesma esperança que Jesus nos ensinou com sua vida e sua prática, pois, não se concebe a possibilidade de anunciar o Evangelho sem que este ilumine, infunda alento e esperança para a existência humana ${ }^{42}$. Enfim, a escola católica é chamada a resgatar a identidade com que foi pensada em seus primórdios e incluir as famílias para que participem do processo formador como tarefa primordial da pastoral educativa ${ }^{43}$.

A esperança como teologia da história, nesta segunda parte do Documento em estudo, apresenta boas motivações que nos impulsionam para a missão da Igreja: reacende nossa esperança como teologia da história, oferece elementos para uma nova concepção que os bispos dão à religiosidade popular, como jeito típico que os nossos povos têm de manifestar e viver a fé professada na Igreja de Jesus Cristo.

Outra motivação que nos dá esperança, e tem o respaldo firme e indispensável do Vaticano II, é a atitude humilde e autêntica dos nossos bispos de se colocarem no itinerário dos discípulos missionários, nos processos formativos do povo de Deus, com critérios e lugares distintos. Nesse contexto, convocam os Centros educativos católicos, e enfatizam, com especial atenção, a Iniciação Cristã, a Catequese permanente e a Formação teológica e pastoral do laicato. Trata-se da revitalização da vocação batismal, sua ampliação eclesial e social, que chama todos e todas à santidade.

A concepção de esperança como teologia da história, nesta segunda parte do Documento, a nosso ver, sublinha três elementos teológico-pastorais que

\footnotetext{
${ }^{41}$ DAp., 331, que cita a Evangelii nuntiandi, (EN), de Paulo VI, S. Paulo, Paulinas, 1978, parágrafo, 19, no qual se detém em apresentar a criação de um processo de evangelização em todos os extratos da humanidade.

${ }^{42}$ Cf. DAp., 333.336

${ }^{43}$ DAp., 337.
} 
apresentam algo novo na orientação dada pelos nossos bispos. O primeiro elemento é a revitalização da vocação batismal de todo o Povo de Deus e de cada pessoa batizada. Esta é a esperança que deve continuar na construção de uma nova história ${ }^{44}$. O segundo elemento teológico-pastoral desta esperança é a alegria que o testemunho da fé traz para todos os batizados e batizadas, os quais anunciam a Boa Nova e assumem as conseqüências que podem advir da mesma. Por fim, o Documento aborda o itinerário esperançoso e direcionado à plenitude, que é, viver a comunhão com todos os povos, como Povo de Deus, em diálogo ecumênico e inter-religioso.

\section{Ressonâncias teológicas vindas do contexto histórico}

O transfundo histórico desta segunda parte, a nosso ver, tem como centro, o reforço da cristologia viva que funciona como caixa de ressonância das linhas de orientação pastoral assumidas ao longo do Documento. Em primeiro lugar, destaca-se a pessoa de Jesus de Nazaré na história trinitária, como Deus conosco, e, portanto, Senhor da história ${ }^{45}$. Foco central é o Mistério da Encarnação a partir da qual irrompe o seguimento de Cristo o qual destaca o ser e o agir de Jesus durante a sua vida, prática que o leva à experiência da kênosis. Coroa este parágrafo a citação de Filipenses, 2, 6-11, onde se evidencia a condição divina do Filho e o esvaziamento de si mesmo, assumindo a condição de servo. Assumir o trabalho do servo, do escravo, naquele contexto, era, realmente, "virar a mesa", colocá-la de pernas para cima. Esta é a grande virada histórica feita por Jesus e coroada na Última Ceia com o lava-pés. Quem dá esta virada na história, se faz testemunha do seguimento e torna-se o novo sujeito da história ${ }^{46}$.

Prosseguindo nesta reflexão, interpretada segundo o espírito que perpassa todo o Documento, pode-se dizer que os elementos históricos nos quais a esperança imprime seu timbre, inspiram-se ainda, em João, na sua Primeira Carta e no Evangelho da sua comunidade. Importante destacar a ênfase dada à síntese do método empregado por João, ao falar do chamado do Senhor, à pessoa que

\footnotetext{
${ }^{44} \mathrm{O}$ autor que ora citamos fala de que o sentido a história é uma realidade impregnada de esperança a ponto de mudar a própria história que se realiza no presente humano: cf. LUBAC, H. de, Paradosso e mistero della Chiesa, Milano, Jaca Book, 1997, p. 13-15

${ }^{45}$ Recomenda-se a leitura do autor TRIGO, P., Criação e História, Petrópolis, Vozes, 1988, sobretudo o primeiro capítulo em que o ponto de partida dos elementos que se seguem, é a experiência de fé do Povo de Israel que culmina com a criação da nova história.

${ }^{46}$ Cf., DAp., 242-243
} 
o busca: "O que procuram"? (Jo1,38). A resposta a esta pergunta é o convite a fazer uma experiência: "Venham e verão" (Jo 1,39). O Documento afirma que esta narrativa é vista nas diferentes apresentações dos quatro Evangelhos. Segundo os bispos, tal convite permanece, na história, como síntese do único método da fé cristã ${ }^{47}$. Venham e verão!

No quadro desta afirmação, na qual o VER a realidade em que vivemos é precedida por uma pergunta que tem como resposta "Venham e verão", traz presente, outra vez, o método adotado pelos bispos no início do Documento ver-julgar-agir - e que, depois, ao longo do mesmo, eles o perdem e ao mesmo tempo o retomam quando afirmam que a "fonte", a partir da qual nasce a nossa evangelização, não exclui o "lugar social" em que vivemos e nos movemos, mas que deve partir deste locus.

$\mathrm{Na}$ aplicação deste método apresentado pelo Documento, e, segundo a atenta interpretação que fazemos, mais uma vez constatamos, não sem surpresa, a importância que é dada à piedade popular como modo legítimo de viver a fé, onde se recolhem as mais profundas vibrações, de grande parte de uma "original experiência histórica e cultural dos pobres deste Continente ${ }^{48}$. Junto a esta ênfase cristã que faz história, Maria, a discípula e missionária é apresentada como a Mulher que teve uma missão única na História da salvação ${ }^{49}$. A esperança dos pobres que cobre toda a expectação dos nossos povos, marca a História da salvação com a plenitude dos tempos, isto é, com a vinda do Salvador para o mundo, trazido pela Mãe do Filho de Deus, Jesus Cristo (cf. Gl 4,4).

A nova história está dando continuidade ao caminho começado, diz a Conferência, pois, resgata os mártires do nosso Continente, que com "valentia" perseveram na promoção dos direitos das pessoas, no discernimento crítico da realidade, à luz do ensino social da Igreja, fazendo memória, ou melhor, trazendo para o nosso tempo presente, a fé dos apóstolos e dos santos e santas, que, como sementes do Evangelho, viveram e vivem sua fé, testemunham, com suas vidas, serem lugares privilegiados de encontro com Cristo ${ }^{50}$. A história testemunha a herança que estas pessoas nos deixaram e o renovado ardor missionário de seu estilo de vida ${ }^{51}$.

${ }^{47}$ Cf. DAp., 243 a 247.

${ }^{48}$ DAp., 264

${ }^{49}$ Ibid., 267.

${ }^{50}$ Segundo GUTIÉRrEZ, G., O Deus da Vida, S. Paulo, Loyola, 1992, em suas páginas, 133ss, os cristãos estão formando uma nova consciência que se expressa na doação total de uma vida vivida no compromisso que desabrochou com o Vaticano II.

${ }^{51}$ Cf. DAp., 273-275 
Fato histórico é, também, o modo positivo, com que o Documento fala das Comunidades Eclesiais de Base, em vários parágrafos, como lugares de comunhão e a contribuição que estão dando na formação de mulheres e homens comprometidos com a fé da Igreja até o ponto de derramar seu sangue ${ }^{52}$.

Em síntese, pode-se falar das ressonâncias teológicas vindas do firme propósito que os bispos manifestaram, ao afirmar como centralidade de todas as orientações pastorais, a de que devemos recomeçar a partir do Cristo. Nesse sentido, a esperança como teologia da história se encontra dentro de três expressivas dinâmicas que mobilizam a história da Igreja do nosso Continente, como História da salvação.

A primeira delas é a dinâmica de Cristo como Senhor e Centro da História $^{53}$, que perpassa toda esta segunda parte do Documento, sem excluir o lugar social a partir do qual anunciamos o Cristo que nos interpela com esta pergunta-resposta: "O que procuram"? "Venham e verão". Pois, evangelizar é sempre estarmos abertos a tudo o que nos rodeia e ver a realidade como Jesus a viu e a interpretou e como Ele deixar-se interpelar para uma fé comprometida.

A segunda dinâmica é o resgate que o Documento faz da herança deixada por tantas pessoas, fiéis seguidoras de Jesus Cristo que $\mathrm{O}$ seguiram até o derramamento de seu sangue para testemunhar os valores do Evangelho e a revelação do Deus Uno e Trino. A Comunidade divina, na pessoa de Jesus Cristo, vivo e ressuscitado entre nós, no tempo presente, tempo kairótico que constrói a verdadeira história missionária permite que sejamos comunidade de fé e comunidade que aponta para o Reino que luta por uma Igreja que sempre mais seja sinal do Sacramento do Pai.

Finalmente, a dinâmica que mobiliza os nossos povos na vivência de sua fé, impulsionados pelo Espírito que os fortifica na caminhada terrena ${ }^{54}$, junta-se a atração que Maria tem sobre as multidões de fiéis que a cultuam como Mãe de Deus, e, com os nomes da originalidade de cada cultura. Por isso, a presença de Maria, na Igreja, dá uma visão feminina da mesma Igreja,

\footnotetext{
${ }^{52}$ Cf. DAp., 178-179

${ }^{53}$ Cf. ROXO, R. M., O Senhor e a História, Petrópolis, Vozes, 1969, p. 70ss. Nestas páginas o autor se detém em fundamentar as origens e o acolhimento trinitário da história humana.

${ }^{54}$ Cf. BOFF, Lina, Espírito e Missão na teologia da época. Um enfoque histórico-teológico: 18501930, S. Paulo, Paulinas, 2a ${ }^{\text {a }}$ edição, 2003, p. 133ss

---, A autora trabalha a realização da esperança na prática de Jesus através dos gestos dos discípulos os quais apontam para a construção de uma nova história. Cf. Da esperança à vida plena. Vivendo as realidades que entrevemos, Juiz de Fora, Editar Editora Associada, 2010, p. 24-25.
} 
deixando na sombra a instituição androcêntrica, funcional e burocrática ${ }^{55}$. Acreditamos que, não foi sem outras razões a escolha do lugar que o papa fez: celebrar a V CELAM próxima à fé de romeiros e romeiras que visitam o Santuário de Aparecida, cheios de esperança e de fé numa nova história que tem uma Mãe, e, como centro de sua caminhada por este mundo, o Filho de Deus na Comunidade divina do Pai e do Espírito Santo. Não se pode negar que a Conferência de Aparecida se realizou também, sob a influência do povo romeiro que visitava o Santuário Nacional.

\section{A esperança na terceira parte do Documento: $A$ vida de Jesus Cristo para nossos povos}

O Documento aqui, entra, plenamente, na missão atual da Igreja Latinoamericana e Caribenha. A objetividade e a consciência crítica com que se deve olhar a realidade e saber pensa-la e realiza-la de forma prática e construtiva nos leva a sermos pessoas atentas aos fundamentos teológicos de toda ação evangelizadora e pastoral, para mantermos o dinamismo missionário que deve impregnar todas as estruturas eclesiais, sobretudo aquelas que já não favoreçam a transmissão da fé. Tal processo é chamado de "conversão pastoral", exigência que insiste em deixar uma pastoral de conservação de lado, para concretizar uma dinâmica pastoral, decididamente, missionária, continental e ad gentes ${ }^{56}$, mobilizadora, portanto.

Trata-se de converter a Igreja toda e cada Igreja Particular, para que faça desabrochar sua vocação missionária, com a finalidade de fomentar uma conversão pastoral, tendo à frente, os episcopados, as dioceses e todas as Conferências do Continente inteiro. A nosso ver, esta orientação dada pelo Documento de Aparecida, sublinha a responsabilidade das instituições eclesiásticas. Estas são motivadas a manterem os olhos abertos sobre a realidade dos nossos povos, os quais cultivam uma fé que não contradiz a esperança e nem as expectativas humanas com relação a recuperar a esperança cristã na sua específica missão na história ${ }^{57}$.

\footnotetext{
${ }^{55}$ Cf. DAp., 268

${ }^{56}$ Cf. Documento de Aparecida, 365-366; 370. 372; 379s

${ }^{57}$ Cf. MOLTMANN, J., Teologia da Esperança. Estudos sobre os fundamentos e as conseqüências de uma Escatologia cristã, S. Paulo, Loyola, 2005, p. 43: Segundo o autor, o verdadeiro presente que o ser humano pode receber me vida, nada mais é do que a eternidade imanente no tempo.
} 
Dito isto, a concepção de esperança como teologia da história, nesta terceira parte, se encontra poucas vezes em relação às duas primeiras partes do Documento. A esperança que constrói uma nova história encontra-se no contexto dos capítulos VIII que se intitula, Reino de Deus e Promoção da dignidade humana; encontra-se no capítulo X, que leva em conta. Nossos povos e a cultura e poucas menções na Conclusão do Documento.

Mais adiante, os bispos afirmam ainda, que a Igreja está convocada a ser advogada da justiça e defensora dos pobres, para despertar esperança, porque, "se não há esperança para os pobres, não haverá para ninguém, nem sequer para os chamados ricos" 58 .

A esperança dos nossos povos se alimenta com as conquistas do presente, graças à prática da tendência inata que estes povos alimentam no compartilhar os dons e os bens que vêm de Deus e da partilha, através de mediações inteligíveis ao saber prático que eles têm de suas tradições culturais e religiosas. Esta esperança compromete-se na construção de um futuro de dignidade e justiça e aspira aos dons mais altos ${ }^{59}$.

A esperança como teologia da história, é, também, levar em conta o espírito com que os bispos empregam a palavra esperança no contexto do diálogo positivo que o Documento estabelece com a pluralidade de culturas vividas no Continente da Esperança. Os nossos bispos assumem o compromisso de uma urgente missão que pede a construção de uma nova história: a de impedir que a Igreja se instale na sua comodidade, no seu estancamento e na sua indiferença, diante do sofrimento dos pobres do Continente ${ }^{60}$. Não só, mas que Deus habita a cidade e que se faz necessário que saiamos dos nossos templos para ir ao encontro das pessoas que buscam a mesma verdade que anunciamos e nos convoca a abrir-nos ao diálogo e à diversidade das culturas ${ }^{61}$.

Em nome desse inadiável compromisso, repetimos aqui, o que já afirmamos acima, empregando a linguagem de Aparecida: esperamos um novo Pentecostes que nos livre do cansaço, da desilusão, da acomodação ao ambiente e que a vinda desse Espírito Santo nos renove na alegria e na esperança ${ }^{62}$. Cabe dizer que este pronunciamento episcopal cobre, em grande parte, algumas inconsis-

\footnotetext{
${ }^{58} \mathrm{DAp}, 395$.

${ }^{59}$ Cf. DAp., 536.

${ }^{60}$ Cf. DAp., 362. A leitura do autor aqui citado não só iluminou a elaboração do parágrafo em seu contexto, mas também ofereceu elementos teológicos para tal elaboração. Cf. LIBÂNIO, J. B., Utopia e Esperança cristã, S. Paulo, Loyola, 1989, p. 133ss.

${ }^{61}$ Ibidem, 522; 536.537.

${ }^{62}$ Cf. DAp., 362.
} 
tências de linguagem que se apresentam em tantos parágrafos da Conferência de Aparecida. O mais importante é que os bispos do extenso Continente deram um testemunho de comunhão e de unidade, que, em breve, terá seus frutos de sabor inconfundível para todo o Cristianismo que nasce da fé no Ressuscitado.

Pode-se sintetizar esta concepção de esperança como teologia da história, em três elementos: primeiro, queremos viver a esperança de que, construir o Reino de Deus e promover a dignidade da pessoa humana, confirma a opção preferencial pelos pobres que se remete a Medellín para revitalizar a história que estamos construindo, opção que se remete à cristologia; segundo, alimentamos com fé, a esperança de que a cultura dos nossos povos continue atualizando as opções de Puebla e Santo Domingo, por uma evangelização inculturada que aponte caminhos para a solidariedade, a reconciliação e a integração entre os povos de todo o Continente; e finalmente, queremos construir a esperançada missionariedade por uma busca criativa, realista e confortadora alegria de evangelizar ${ }^{63}$.

Somos chamados e chamadas a tomar posição, a decidir por uma prática da fé e da esperança que não é uma evasão, um escape ou uma fuga para outro lugar. Mas a verdadeira esperança cristã vivida na história, pelo contrário, nos impele a realizar, neste momento histórico, uma evangelização aberta ao ecumenismo e ao diálogo interreligioso, uma evangelização que inclui todos e todas as culturas e tradições de credos. Emerge o conceito aberto de Revelação que encontramos em toda a Constituição Dei Verbum.

\section{Ressonâncias teológicas vindas do contexto histórico}

Neste parágrafo, queremos enfatizar a importância que os bispos dão ao Vaticano II, quando afirmam que a Igreja se reconhece nos ensinamentos do Vaticano II, como "sacramento" de unidade do gênero humano. Ainda que o ver-julgar-agir do Vaticano II se debruce sobre a realidade européia, nós vivemos e aplicamos suas orientações e seu espírito, passando por Medellín e em parte, por Puebla, como já o dissemos na parte primeira deste artigo ${ }^{64}$. A partir desta leitura cristã da história, os bispos não desconhecem a história dos nossos povos, história carregada dos problemas mais diferentes e distintos que hoje afetam o Continente; reconhecem a ambigüidade do atual processo de

\footnotetext{
${ }^{63}$ Cf. Conclusão: 54. 541. Faça um cf. também com a Exortação Apostólica sobre a evangelização no mundo contemporâneo (Evangelii nuntiandi) 80, de Paulo VI.

${ }^{64}$ BOFF, Lina, "A Esperança como Teologia da História", in ATeo, fasc. 35 (2010), p. 133ss.
} 
globalização, sobretudo quando se trata da integração dos povos e do modo que cada Conferência Episcopal adota ao aplicar as orientações deste Concílio ${ }^{65}$.

Entendemos que o Documento de Aparecida concebe a teologia da história, como uma "mudança de época". Esta expressão não pode ser confundida com a concepção de história dos sistemas abertos, que concebem o progresso e as descobertas da ciência e da técnica, com suas variadas expressões, como avanços ou retrocessos da história. No entender dos bispos, a expressão "mudança de época", significa: reviver os ensinamentos de Cristo no contexto histórico em que nos encontramos ${ }^{66}$; refazer a história com a mesma dinâmica com que Jesus viveu e nos revelou a vida íntima de Deus em seu mistério insondável, que é a comunhão trinitária, do amor do Pai para com o Filho, e deste para com o Pai, de onde irrompe a Pessoa do Espírito Santo, como força que une e reúne tudo em Comunidade de Amor. Este Amor faz história porque se manifesta na Palavra dirigida ao ser humano com quem estabelece uma relação humana e com toda a criação. Esta relação que se dá na história, vai divinizando o ser humano e recapitulando tudo em Cristo, dinâmica divina no humano, que marca a nova história, que é a História da salvação ${ }^{67}$.

Nesta percepção, trata-se de dar um sentido originário da nossa existência que se sente esvaziada pela falta de unidade interior, falta de referências que ultrapassem a nossa condição de criaturas em busca de seu Criador ${ }^{68}$. O ser humano vive sua fé de modo fragmentado como é fragmentada a nossa sociedade. Encontra-se aqui, o sentido profundo e abrangente da teologia da história, segundo o Documento, "na história do amor trinitário". Nesta história, Jesus de Nazaré, é Caminho, Verdade e Vida, porque sua Encarnação, na história, sua pregação, morte e ressurreição, inauguram a Nova História que inclui os demais conceitos dos sistemas abertos. É nesta concepção que nasce o discipulado de homens e mulheres, como novos sujeitos que dão continuidade à História inaugurada pelo mistério de Cristo. A partir desta concepção, descobre-se que, os nossos povos reconhecem as mesmas raízes históricas da

${ }^{65}$ Cf. DAp., 478. 523. 525.

${ }^{66}$ Comentário ao Documento, AMADO, J. P., "Mudança de época e conversão pastoral: Uma leitura das conclusões de Aparecida”, in ATeo, Ano XII, fasc. 30 (2008), p. 301-316.

${ }^{67} \mathrm{Cf}$. BOFF, Lina, Da esperança à vida plena. Vivendo as realidades que entrevemos, Juiz de Fora, Editar Editora Associada, 2010, p. 22s; 88s.

${ }^{68}$ Cf. PEÑA, R. de la, Teologia da criação, S. Paulo, Loyola, 1989. Em tal contexto, o autor citado sublinha o conceito explícito cunhado pela fé israelita, que é a aliança e não o poder com que Deus se revela nos fenômenos da natureza e da sua criação plasmada por seu amor. 
fé e da cultura, as quais caracterizam os povos da grande "pátria madre", e que os une na caminhada histórica da fé ${ }^{69}$.

O Documento propõe como meta de revitalização do Evangelho, que deve marcar a nossa história de evangelização sempre renovada, fazer história como Jesus fez, vivendo a audácia e a profecia do discurso escatológico de Mateus, que narra as atitudes concretas de uma cristologia viva que ele apresenta nos capítulos 24 e 25 de seu Evangelho (cf. Mt 24-25). Torna-se mais clara ainda a tomada de posição que os bispos assumem, a partir da palavra do papa, em seu discurso inaugural, que afirma: "a opção preferencial pelos pobres está implícita na fé cristológica" ${ }^{\circ}$. Em seu discurso inaugural, o papa enfatiza que a catolicidade dos nossos povos deve ser cultural e não só geográfica, pois, esta fé universal foi, e está sendo expressa na arte, na música, na literatura, e sobretudo, nas tradições religiosas unidas pela mesma história e pelo mesmo credo $^{71}$.

A concepção de história, em seu sentido de fé, portanto, e dentro do contexto da V CELAM, marca a nossa caminhada de evangelização histórica, pela orientação esperançosa e cheia de sentido que o Documento nos dá. Os bispos, aqui, não citam o Documento de Puebla, mas cabe muito bem retomá-lo em um de seus parágrafos, onde se afirma que a Igreja deve ser como um escola que educa as pessoas para serem capazes de construir uma história que leve, com Cristo, a história até o Reino de Deus ${ }^{72}$. Feito este comentário, e, tendo em vista, algumas vertentes abertas à ação do Espírito, que Aparecida apresenta, pode-se dizer que estas são interpretadas da seguinte forma.

A primeira delas se constitui em atualizar, em cada pessoa do povo de Deus do extenso Continente, o chamado que recebemos do Senhor da Vida: a de sermos discípulas e discípulos missionários de Jesus Cristo em nossa realidade, pintada com cores variadas, como é variada a interpretação feita pelas pessoas estudiosas das ciências sociais, e da situação mundial globalizada ${ }^{73}$. Não cabe aqui falar de tal variedade.

A segunda vertente nos mostra o compromisso urgente que temos de agir, em força do chamado que o Senhor nos faz: a de atuarmos com todas as nossas

${ }^{69}$ Documento de Aparecida, parágrafos: $109 ; 242 ; 524 ; 543$. Faça um cf. com o artigo citado acima do autor, AMADO, Joel Portella.

${ }^{70}$ Cf. DAp., 392 e Discurso Inaugural, 3

${ }^{71}$ Cf. Discurso Inaugural, 1, retomado pelos bispos, especialmente, nos parágrafo 478-479.

${ }^{72}$ Cf. A evangelização no presente e no futuro da América Latina. Puebla: Conclusões (DP), III Conferência Geral do Episcopado Latino-Americano, S. Paulo, Loyola, 1979, 274.

${ }^{73}$ Cf. PIAZZA, O., A esperança. Lógica do impossível, S. Paulo, Paulinas. Neste ponto o autor nos fala da esperança do Crucificado que foi vivida de forma paradoxal e que por este motivo exige do ser humano, um ato supremo de liberdade e doação total da própria vida. 
energias na situação em que vivem os nossos povos no que diz respeito à uma cultura de menos vida, a uma situação econômica desastrosa, sócio-política e étnica, necessitadas de dignidade. Nesta hora histórica é preciso testemunhar o encontro pessoal com Jesus Cristo que se revela, nesta realidade esperançosa e ao mesmo tempo contraditória. O discípulo e a discípula missionários, são a manifestação da presença viva de Cristo que chama à santidade, que anima com a força de seu Espírito, que indica os lugares da vivência da comunhão e os caminhos de uma espiritualidade trinitária vivida junto com o povo. É o Cristo vivendo nos discípulos e nas discípulas de todas as culturas e de todos os continentes ${ }^{74}$.

Neste ponto cabe também uma citação de Puebla que não se vê no Documento, a do incentivo à dimensão universal da evangelização como meta suprema dos povos entre si e dos povos com o Deus Uno e Trino, citação feita no parágrafo 368 de Puebla. Este sela a nossa experiência de fé na sua dimensão de universalidade e continuidade dentro de um Cristianismo que tem seu jeito próprio de expressar esta fé manifestada na esperança e na criatividade do Espírito que vai além-fronteiras. Assim fala Puebla: finalmente, chegou para o nosso Continente, a hora de darmos da nossa pobreza para oferecer algo de importante: o nosso sentido de salvação e libertação, a riqueza da nossa religiosidade popular, a dinâmica das nossas Comunidades Eclesiais de Base, a floração dos ministérios do laicato, sobretudo, a nossa esperança e a alegria da nossa fé. Precisamos aprofundar e ampliar nossos esforços missionários ${ }^{75}$.

Por fim, marca a esperança como teologia da história, nas conclusões da V CELAM, o fato de que, nossos povos encontram, em Cristo, a vida que procuram e buscam. Por isso, para se constituir em discipulado missionário, cada povo precisa caminhar para uma vertente formativa buscada na Palavra de Deus que ilumina o olhar sobre a realidade em que vive e o impele a uma prática da fé esperançada nos conteúdos desta Palavra. Esta é a atitude que abre para o compromisso missionário, não só como pessoa individual, mas como povo e como comunidade chamada para a missão. É desta missão que nasce a verdadeira Igreja de Jesus Cristo, pois, sua missão é anunciar a

\footnotetext{
${ }^{74}$ Para esta reflexão utilizamos a obra do mestre, de grata memória, PASTOR, F. A., O Reino e a História. Problemas Teóricos de uma Teologia da Práxis, S. Paulo, Loyola, 1982, sobretudo as páginas, 101-104

${ }^{75}$ Cf. DP, 368, PASTOR, F. A., O Reino e a História. Problemas Teóricos de uma Teologia da Práxis, S. Paulo, Loyola, 1982.
} 
Boa Nova do Cristo Ressuscitado à luz e à inspiração dos critérios ditados pelo querigma e pela ação do Espírito que suscita os diferentes, distintos e variados carismas para o serviço da comunidade de fé. Esta é a desinstalação que todos e todas esperamos da Igreja e de suas instituições, dos movimentos e das milhares de comunidades que fé que sempre mais nascem, dia-a-dia, com a finalidade de construirmos uma nova história marcada pela esperança e pela doação da vida no amor que Cristo nos deixou como herança do Eterno à humanidade toda.

\section{A modo de conclusão}

Seria ousado concluir alguma coisa a partir do Documento de Aparecida, uma vez que só com o tempo poderemos avaliar seu peso teológico e pastoral. Se, logo no início do Documento, os bispos consideram com acuidade as grandes mudanças do mundo e seu reflexo, em nosso Continente, sobre os povos que o habitam, postulam, todavia, a esperança vivida por Jesus Cristo, que mudou a história de todos os povos da terra. Esta esperança consente a todos os povos, a alegria, o gozo, a solicitude e o compromisso com a promoção humana e a partilha dos bens que promovem a vida. Afirmam uma esperança humana que se encontra no âmago da história vivida por Jesus, pois, é a esperança que direciona para uma "mudança de época". Ao lado desta verdade histórica, existe uma verdade mais íntima, mais alta e mais decisiva, que não é facta bruta, porque transcende a verdade, puramente, histórica. É a verdade do grande mistério de um Deus que se encarna e arma tenda entre nós, Jesus Cristo, Senhor da história.

A concepção de esperança como teologia da história é sublinhada por elementos teológico-pastorais que revitalizam a vocação batismal de todo o Povo de Deus e de cada pessoa sobretudo, a dimensão espiritual e comprometida do batismo. Esta dinâmica, que se dá na história, resgata a herança deixada por tantas pessoas que seguiram Jesus Cristo até o derramamento de seu sangue para testemunhar os valores do Evangelho e a revelação deixada pelo Senhor ressuscitado como centro e Senhor da história. Pode-se dizer que, em Aparecida, os bispos evidenciam duas coisas importantes para o testemunho da fé dos nossos povos. A primeira é o testemunho dos nossos mártires que acabamos de apresentar; e a segunda, é o testemunho da fé ativa e da 
presença constante da mulher na dinâmica da história que construímos com o povo. As muitas mulheres de hoje que presidem o processo de evangelização tem, em Maria de Nazaré, a exemplaridade da Mãe de Deus que atrai filhos e filhas para o Filho que ela gerou no Mistério da Encarnação.

Evidenciamos uma concepção de esperança como teologia da história, que afirma e confirma a opção preferencial e evangélica pelos pobres como atualização das Conferências anteriores, opção que se expresse na construção de uma cultura de vida e uma missionariedade menos tímida e conservadora, mais criativa e menos medrosa diante das interpelações do Espírito que dinamiza e desinstala. O discipulado de Cristo precisa de todos os carismas suscitados por este Espírito para fazer da Igreja e de suas instituições, espaços privilegiados de vivência da fé, do testemunho da esperança na Promessa feita por Jesus Cristo. É inadiável o fato de que o discípulo e a discípula se abram para a missionariedade dos seus mais próximos e de além-fronteiras, que se dediquem aos novos areópagos das nossas grandes cidades, das comunidades humanas que clamam por mais vida e participação nos centros de decisão, para que se viva uma atuação ética na vida pública e política, para que se que crie cidadania e solidariedade humana e cristã, até os confins da terra.

\section{Referências Bibliográficas}

BALTHASAR, H. U. von, Verbum caro. Saggi Teologici 1, Brescia, Morceliana/ Milano, Jaca Book, 2005.

BOFF, L., A ressurreição de Cristo. A nossa ressurreição na morte, Petrópolis, Vozes, 1972.

BOFF, Lina, Espirito e Missão na teologia da época. Um enfoque históricoteológico: 1850-1930, S. Paulo, Paulinas, 1998, 2ª edição, 2003.

, Da esperança à vida plena. Vivendo as realidades que entrevemos, Juiz de Fora, Editar Editora Associada, 2010.

CELAM, A igreja na atual transformação da América Latina à luz do Concílio. Conclusões de Medellín, Conselho Episcopal latino-americano, Petrópolis, Vozes, 1970. 
CELAM, A evangelização no presente e no futuro da América Latina. Puebla: Conclusões, S. Paulo, Loyola, 1979.

CELAM, Santo Domingo, IV Conferência Geral do CELAM, Nova evangelização, promoção humana, cultura cristãa, Petrópolis, Vozes, 1992.

CELAM, Documento de Aparecida. Texto conclusivo da V Conferência Geral do Episcopado Latino-Americano e Caribenho (DAp), S. Paulo/Brasília, Edições CNBB/Paulus/Paulinas, 2007.

GUTIÉRREZ, G., O Deus da Vida, S. Paulo, Loyola, 1992.

IMPERATORI, M., H.U. von BLATHASAR: Uma teologia drammatica della storia. Per um discernimento dialógico nella modernita, Pontifício Seminário Lonbardo in Roma, 2001.

KEHL, M., "E Dio vide che tutto era cosa buona". Uma teologia della creazione, Brescia, Queriniana, 2009.

LIBÂNIO, J. B., Utopia e Esperança cristã, S. Paulo, Loyola, 1989.

LUBAC, H. de, Paradosso e mistero della Chiesa, Milano, Jaca Book, 1997. , Cattolicismo. Aspetti sociali del dogma, Milano, Jaca Book, 1992, p. 89 s

MOLTMANN, J., Teologia da Esperança. Estudos sobre os fundamentos e as conseqüências de uma Escatologia cristã, S. Paulo, Loyola, 2005.

PASTOR, F. A., O Reino e a História. Problemas Teóricos de uma Teologia da Práxis, S. Paulo, Loyola, 1982.

PAULO VI, Exortação Apostólica sobre a evangelização no mundo contemporâneo (Evangelii nuntiandi), S. Paulo, Paulinas, 1978.

PEÑA, R. de la Teologia da criação, S. Paulo, Loyola, 1989.

PIAZZA, O., A esperança. Lógica do impossivel, S. Paulo, Paulinas.

POLITI, S., História e Esperança, S. Paulo, Paulinas, 1996.

ROXO, R. M., O Senhor e a História, Petrópolis, Vozes, 1969. 
SALAS, G. L., Teologia e Historia en desafio. Nervios vitales de la Teologia moderna, Sal Santander, Sal Terrae, 1969.

TRIGO, P., Criação e História, Petrópolis, Vozes, 1988.

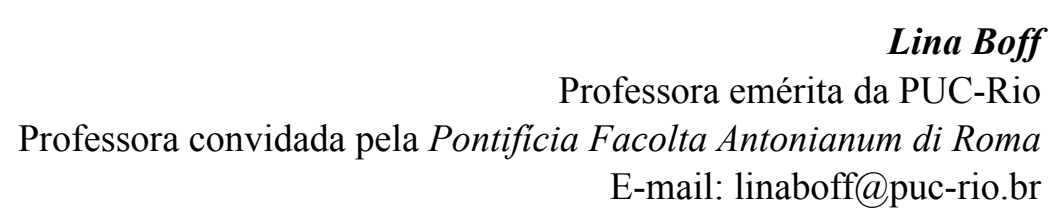

Artigo Recebido em 13/03/2012

Artigo Aprovado em 14/05/2012 